\title{
An Investigation of the Opinions of Pre-service Midwives and Nurses Regarding Lifelong Learning
}

\author{
Mukaddes Örs ${ }^{1, *}$, Mustafa Kılınç ${ }^{2}$ \\ ${ }^{1}$ Department of Nutrition and Dietetics, Faculty of Health Sciences, Amasya University, Turkey \\ ${ }^{2}$ Department of Measurement and Evaluation in Education, Faculty of Education, Mehmet Akif Ersoy University, Turkey
}

Copyright $\bigcirc 2017$ by authors, all rights reserved. Authors agree that this article remains permanently open access under the terms of the Creative Commons Attribution License 4.0 International License

\begin{abstract}
The objective of this study is to determine the lifelong learning tendencies of students from the midwifery and nursing department at a Faculty of Health Sciences, and to reveal whether these tendencies differ with respect to the some variables. It further attempts to show some significant differences in the students' lifelong learning tendency levels according to certain demographic attributes (i.e., department, gender, and leisure). In accordance with the above purpose, the answers to the following questions are sought. 1 . What are the lifelong learning tendency levels of midwifery and nursing students? 2. Are there any significant differences in lifelong learning tendency levels between the groups of students that may be formed according to demographic attributes? This is a descriptive study for a situation determination, on which a scanning model is grounded. The target population of this study consists of 356 students enrolled in midwifery and nursing departments. None of the sampling methods are used in this research as the researchers aimed to reach all 356 individuals in the target population. The data were collected from 333 students, although the data concerning 14 students were not included in the analysis due to a lack of response. The measurement scale used to measure the lifelong learning tendencies consists of two parts. Items regarding the demographical attributes constitute the first part and items related to the participants' tendencies toward lifelong learning formed the second part of the measurement tool. SPSS-22.0 was used for the data analysis, where Mann-Whitney $\mathrm{U}$ and Kruskall-Wallis $\mathrm{H}$ tests were conducted to test the hypothesis. The descriptive statistics of the students' demographic attributes were presented. The study's results indicated no significant difference in the lifelong learning tendency levels between the two groups of students making up the study areas (i.e., midwifery and nursing). Therefore, it can be inferred from this result that study areas do not have any significant impact on students' lifelong learning tendency scores. Conversely, the study's results revealed a significant difference in the students' lifelong learning tendencies
\end{abstract}

between the two gender groups (i.e., female and male). The mean observed lifelong tendency scores of the female students was significantly higher than the mean of the male students. In light of the obtained study results, to improve the lifelong learning tendencies of students enrolled on midwifery and nursing courses, educational seminars about the importance of lifelong learning in human lives should be held.

Keywords Lifelong Learning, Midwife, Nurse, University Student

\section{Introduction}

In the twenty-first century, also referred as the information age, individuals are required to cope with geometrically increasing vast amounts of information and to be creative persons who investigate, probe, establish communication with others, adapt to innovations, and be technology-friendly as members of an information society. The lifelong learning approach is considered to be one suggestion of a way to overcome a number of problems in the education system and to make up a number of deficiencies in the education system, which contributes to the economy by employing individuals equipped with this knowledge and competency in their relevant professions (Epçaçan, 2013, 355).

Some researchers address the impact of economic and social changes on adult education. It is reported that changes in the social world and the adult student environment have a significant influence on adults' learning processes, on their preferences as students, and on their educational needs (Örs, 2016b, 15).

In parallel to technological advancements and the increasing ability to access information, there are variations in individuals' expectations and university requirements to include lifelong learning programs in their education programs (Örs, 2016a, 89). 
European Commission (2002) describes lifelong learning as all learning activities that are maintained throughout the lives of individuals to enhance their knowledge, skills, and competencies within a personal, citizen, and social perspective. Organizations, commissions, and the literature describe lifelong learning in different ways.

The most common descriptions used for lifelong learning in the literature are as follows. Ahmed $(2002,22)$ describes lifelong learning as a process which starts at birth and provides individuals, society, and organizations with learning opportunities throughout their lives; and which integrates learning and life both horizontally (by establishing connections between family, society, work, and business) and vertically (from birth to death). Candy (2003) describes lifelong learning as a process whereby individuals gain skills and competencies in order to continue their self-education beyond their formal education, and Crick, Broadfoot, \& Claxton (2004) describe it as whole personal or organizational strategies which include formal, informal, extensive, and self-oriented leaning that persists throughout life. In a broad sense, lifelong learning is a flexible learning process which continues throughout the lives of individuals and takes place in various locations and times (LLCQ, 2017; Miser, 2013). The Union of American Nursing Colleges and the National Union of Nursing consider that lifelong learning is an expectation for professional nursing practices (NLN, 2011).

In the twenty-first century, every professional needs to view their continuing learning skills, that is, the acquisition of learning skills, as an element of their whole lives instead of only a part of it. Accordingly, professionals need to develop themselves in terms of the lifelong learning context so that they can contribute to their professional development (Aspin \& Chapman, 2000; Gopee, 2005; Barnard, Nash and O'Brien, 2005).

Lifelong learning determines what midwives and nurses can accomplish in the future, subject to need, by using complex technology because of evolutionary expansion and the growth and updating of databases. Therefore, in the lifelong learning context, building up information, the acquisition of new information, developing current skills, putting acquisitions into practice, and changing attitudes all need to be taken into consideration (Abruzzese, 1986; Gökçebay et al., 1997; Mouzakitis and Tuncay, 2011; Thurstone, 1992).

It should be realized that midwives and nurses need to possess certain competencies and skills so that they can be professionals who pursue lifelong learning. Gopee (2002) emphasizes that nurses need to have learning skills in the context of continuous learning and self-improvement so that they can be lifelong learners/professionals, and Dickinson (2000) and Maslin (1997) report that they need to be skilled in using information and communication technology, problem solving, and written-verbal communication. Titmus (1999) and Hinchliffe (1994) emphasize that they need skills for self-learning and accessing information resources, respectively.

The fundamental objective is that midwives and nurses maintain their personal and professional development in line with modern approaches through lifelong learning so as to raise the quality of the care and service that they provide; in other words, it is to protect unhealthy/healthy individuals, family, society, and receivers of health services by means of quality service (Abruzzese, 1986; Alspach, 1995; Aspin and Chapman, 2000; Gopee, 2002; Stein, 1998; Taşocak, 2000; Thurstone, 1992).

When studies on lifelong learning competencies from the relevant literature are reviewed, it can be seen that there are only a limited number of studies on the tendencies of midwives and nurses towards lifelong learning in which quantitative and/or qualitative research methods are employed. Hence, the present qualitative study was conducted to determine the lifelong learning tendencies of students from a midwifery and nursing department.

In light of the above information, determining the tendencies of students from the midwifery and nursing department at a Health College and investigating whether their lifelong learning tendencies change with respect to certain variables is a fundamental problem of the present study.

\section{Objective}

The objective of this study is to determine the lifelong learning tendencies of students from the midwifery and nursing department at a Faculty of Health Sciences, and to reveal whether these tendencies differ with respect to the following variables: Gender, department, monthly income, and leisure activities. Within the scope of this objective, we attempted to answer the following questions:

1. What is the lifelong learning tendency level of prospective midwives and nurses?

2. Do the lifelong learning tendencies of prospective midwives and nurses vary with respect to their
a) gender,
b) department,
c) monthly income,
g) leisure activities?

\section{Method}

\section{Method of the Research}

The present study is descriptive research into determining current status and was conducted based on the screening model, an approach that attempts to describe a past or current status or incident in its original form 
(Karasar, 2014).

\section{Population-sampling}

This study's scope is composed of a total of 356 students from the Midwifery $(n=106)$ and Nursing Departments $(n=250)$ at the Faculty of Health Sciences at Amasya University during the 2016-2017 academic period. We tried to include the entire sample in the analysis without using a sampling selection method. Due to sick days or vacations during the research period or incomplete returned forms, the forms that were returned by 333 students (92 midwifery students; 241 nursing students) were included in the analysis. Before the start of the study, the relevant written permission was granted by Amasya University; the students participated in the study on a voluntary basis. The students in the sample were told the objective of the study and they were requested to fill in data collection forms on a voluntary basis.

\section{Data Collection Tools}

The data collection scale comprised two main sections; the first included the students' personal information, and the second included items for collecting data concerning their lifelong learning tendencies.

In order to determine the lifelong learning tendencies of the participating students, "the Scale for Determining Lifelong Learning Tendencies" prepared by Çoşkun (2009) was employed in this study. The scale comprised 27 items in a six-point Likert model with "suits well", "partly suits", "moderately suits", "poorly suits", "partly does not suit", and "not at all" options. The Cronbach's Alpha reliability coefficient of the scale was reported to be .89 , it was estimated to be .90 for the present study. The scale's sub-dimensions were motivation, perseverance, low competence in learning organization, and lack of curiosity. The maximum and minimum total scores that could be achieved on the scale were 162 and 27, respectively.

Before the study, written permission was granted by the Amasya University administration. In addition, the students participated in the study on a voluntary basis. The participants were explained the study's objective and they were asked to fill in information forms voluntarily. After the volunteer students had been explained that the information found by the study would only be evaluated by the survey practitioner, and that it would not be disclosed to any third parties, the students were requested to fill in the survey form. The study was administered by the researcher during the period between 19.03.2017 and 17.04.2017.

\section{Analysis Techniques}

The SPSS-22.0 package software was utilized to analyze the study data. The demographic characteristics of the participating students were analyzed in terms of their frequency and percentage. In order to determine whether the collected study data were normally distributed, Kolmogorov-Smirnov and Shapiro-Wilk tests were conducted.

Because we found that the groups were not distributed normally, non-parametric Kruskal Wallis and Mann Whitney $U$ tests were utilized in triple and dual comparisons, respectively, so as to determine whether the university students' lifelong learning tendency scores differed significantly with respect to their gender, department, and leisure activities (Büyüköztürk, 2010: 155-166; Kalayc1, 2010: 99-106).

\section{Findings}

According to Table 1, the female and male percentages were found to be $83.2 \%$ and $16.8 \%$, respectively, and the percentages of the nursing and midwifery departments were $72.4 \%$ and $27.6 \%$, respectively. In terms of leisure activities, $28.2 \%$ preferred reading, $52.3 \%$ preferred watching $\mathrm{TV}, 6.3 \%$ preferred going to the movie theatre, and $13.2 \%$ preferred sports activities. Regarding their income distribution, it was observed that $66.1 \%$ were in the monthly income group higher than 1.000 TL (Table 1).

Table 1. Descriptive characteristics of the participating students

\begin{tabular}{|c|c|c|c|}
\hline Variables & Group & $\mathrm{n}$ & $\%$ \\
\hline \multirow{3}{*}{ Gender } & Female & 277 & 83.2 \\
\hline & Male & 56 & 16.8 \\
\hline & Total & 333 & 100.0 \\
\hline \multirow{3}{*}{ Department } & Nursing & 241 & 72.4 \\
\hline & Midwifery & 92 & 27.6 \\
\hline & Total & 333 & 100.0 \\
\hline \multirow{4}{*}{ Monthly Income } & 500 Turkish Liras $\leq$ & 33 & 9.9 \\
\hline & 500-1000 Turkish Liras & 80 & 24.0 \\
\hline & 1000 Turkish Liras $\geq$ & 220 & 66,1 \\
\hline & Total & 333 & 100.0 \\
\hline \multirow{5}{*}{ Leisure Activities } & Reading & 94 & 28.2 \\
\hline & Watching Television & 174 & 52.3 \\
\hline & Movie Theatre & 21 & 6.3 \\
\hline & Sports Activities & 44 & 13.2 \\
\hline & Total & 333 & 100.0 \\
\hline
\end{tabular}

According to the Lifelong Learning Scale Sub-Dimension's statistics shown in Table 2, the mean scores of the students from the sub-dimensions were found to be as follows; motivation (30.71), lack of curiosity (28.16), perseverance (27.50), and poor learning organization skill (17.77). On the basis of the finding that the mean scores were below the mean score of the scale, it could be concluded that students in general do not exhibit 
lifelong learning tendencies; they are not open to learning for the rest of their lives; and they do not view learning new knowledge and skills as a fundamental characteristic of their lives. Moreover, it is apparent that lifelong learning is not among the students' priorities; they do not show perseverance against obstacles which they face or discretionary learning circumstances to accomplish their targets; and they show poor learning organization skills.

Table 2. Descriptive Statistics Regarding the Lifelong Learning Tendencies and Sub-Dimensions of Midwifery and Nursing Students

\begin{tabular}{|c|c|c|c|c|c|c|}
\hline Sub-Dimensions & $\mathrm{n}$ & Minimum & Maximum & Mean & Median & Ss \\
\hline Motivation & 333 & 11.00 & 36.00 & 30.71 & 31.00 & 3.81 \\
\hline Perseverance & 333 & 9.00 & 36.00 & 27.50 & 28.00 & 5.21 \\
\hline Lack of Learning Organization Skill & 333 & 6.00 & 36.00 & 17.77 & 17.00 & 8.11 \\
\hline Lack of Curiosity & 333 & 9.00 & 54.00 & 28.16 & 28.00 & 11.21 \\
\hline Lifelong Learning Tendency Scale & 333 & 58.00 & 157.00 & 104.13 & 100.00 & 18.14 \\
\hline
\end{tabular}

According to Table 3, there are no significant differences in the participating university students' lifelong learning tendencies with respect to the departments of midwifery and nursing $(\mathrm{p}>0.05)$. Accordingly, it could be concluded that the department does not influence students' lifelong learning tendency scores.

Table 3. Mann-Whitney U Test Results Regarding Students' Lifelong Learning Tendency Scale Scores According to their Departments

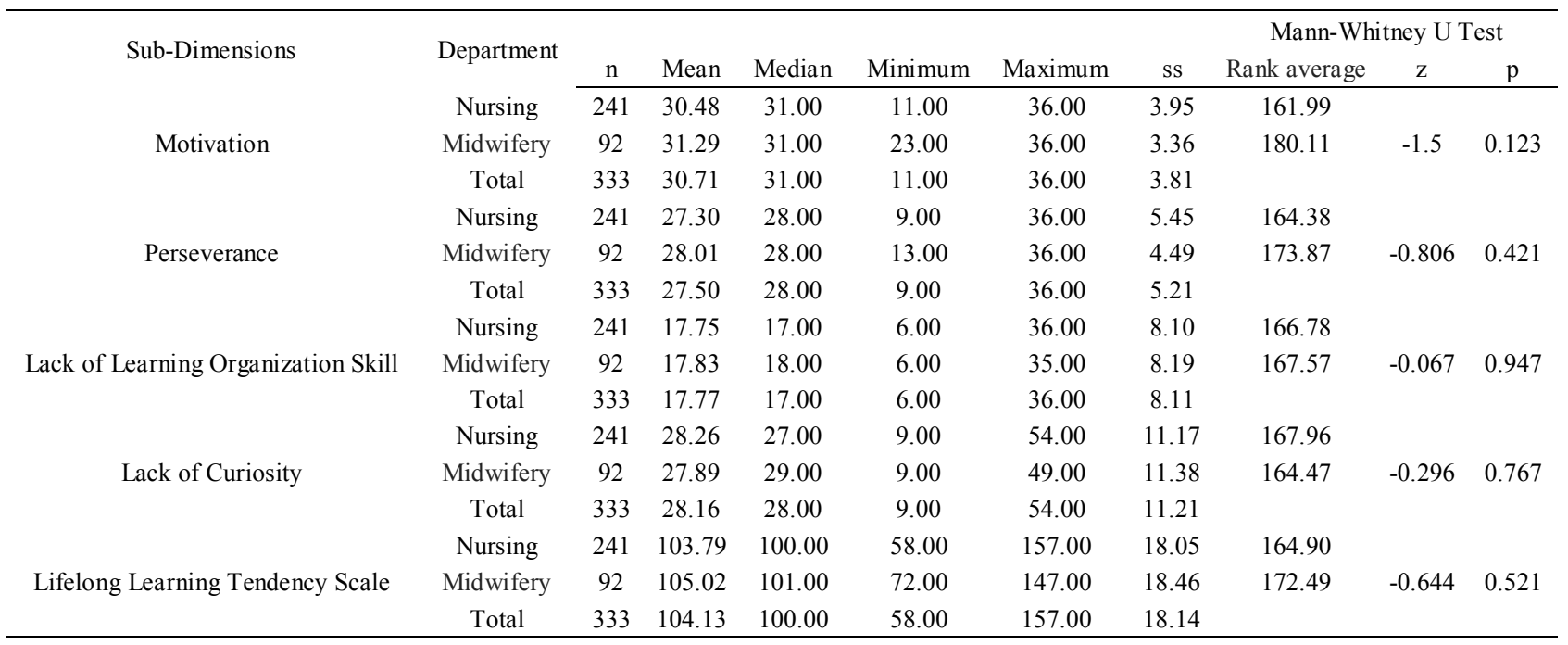

According to Table 4, as a result of the analysis of whether the participating students' lifelong learning tendency levels differed according to their gender, it can be seen that the male and female students' mean scores differ significantly, and that the differences are greater for the male students $(\mathrm{p}<0.05)$. It can be concluded that the students' lifelong learning tendency levels differ significantly in the "poor learning organization skills" and "lack of curiosity" sub-dimensions according to their gender. When the mean scores are considered in terms of gender with respect to the relevant dependent variable, it can be seen that the male students" mean scores for the "poor learning organization skills" and "lack of curiosity" sub-dimensions are higher than those of the females.

Table 4. Mann-Whitney U Test Results Regarding Students' Lifelong Learning Tendency Scale Scores According to the Gender Variable

\begin{tabular}{|c|c|c|c|c|c|c|c|c|c|c|}
\hline \multirow{2}{*}{ Sub-Dimensions } & \multirow{2}{*}{ Gender } & \multirow[b]{2}{*}{$\mathrm{n}$} & \multirow[b]{2}{*}{ Mean } & \multirow[b]{2}{*}{ Median } & \multirow[b]{2}{*}{ Minimum } & \multirow[b]{2}{*}{ Maximum } & \multirow[b]{2}{*}{ ss } & \multicolumn{3}{|c|}{ Mann-Whitney U test } \\
\hline & & & & & & & & Rank Average & $\mathrm{z}$ & $\mathrm{p}$ \\
\hline \multirow{3}{*}{ Motivation } & Female & 277 & 30.87 & 31.00 & 11.00 & 36.00 & 3.71 & 171.18 & & \\
\hline & Male & 56 & 29.88 & 30.00 & 18.00 & 36.00 & 4.19 & 146.35 & -1.7 & 0.077 \\
\hline & Total & 333 & 30.71 & 31.00 & 11.00 & 36.00 & 3.81 & & & \\
\hline \multirow{3}{*}{ Perseverance } & Female & 277 & 27.50 & 28.00 & 9.00 & 36.00 & 5.20 & 168.01 & & \\
\hline & Male & 56 & 27.48 & 27.50 & 18.00 & 36.00 & 5.31 & 162.02 & -0.426 & 0.671 \\
\hline & Total & 333 & 27.50 & 28.00 & 9.00 & 36.00 & 5.21 & & & \\
\hline \multirow{3}{*}{ Lack of Learning Organization Skills } & Female & 277 & 17.04 & 15.00 & 6.00 & 35.00 & 8.17 & 157.97 & & \\
\hline & Male & 56 & 21.39 & 22.00 & 6.00 & 36.00 & 6.78 & 211.65 & -3.8 & $0.0001 *$ \\
\hline & Total & 333 & 17.77 & 17.00 & 6.00 & 36.00 & 8.11 & & & \\
\hline \multirow{3}{*}{ Lack of Curiosity } & Female & 277 & 27.26 & 26.00 & 9.00 & 49.00 & 11.13 & 159.30 & & \\
\hline & Male & 56 & 32.61 & 35.00 & 9.00 & 54.00 & 10.66 & 205.07 & -3.2 & $0.001^{*}$ \\
\hline & Total & 333 & 28.16 & 28.00 & 9.00 & 54.00 & 11.21 & & & \\
\hline \multirow{2}{*}{ Lifelong Learning Tendency Scale } & Female & 277 & 102.67 & 99.00 & 58.00 & 151.00 & 18.03 & 158.67 & \multirow{2}{*}{-3.5} & \multirow{2}{*}{$0.0001 *$} \\
\hline & Male & 56 & 111.36 & 109.00 & 85.00 & 157.00 & 17.05 & 208.19 & & \\
\hline
\end{tabular}


$\begin{array}{lllllll}\text { Total } & 333 & 104.13 & 100.00 & 58.00 & 157.00 & 18.14\end{array}$

According to Table 5, It can be concluded that the students' lifelong learning tendency levels differ significantly in the "Motivation", "Perseverance" and "lack of curiosity" sub-dimensions according to their leisure activities $(p<0.05)$. There are significant differences in the university students' lifelong learning tendency levels with respect to their "leisure activity" preferences of reading and watching TV $(\mathrm{p}<0.05)$. On the other hand, no significant differences can be seen between the leisure activity preferences of sports and going to the movie-theatre $(\mathrm{p}>0.05)$.

Table 5. Kruskal-Wallis H Test Results Regarding Students' Life-long Learning Tendency Scale Scores According to Leisure Activities

\begin{tabular}{|c|c|c|c|c|c|c|c|c|c|c|c|}
\hline \multirow[b]{2}{*}{ Sub-Dimensions } & \multirow[b]{2}{*}{ Leisure Activities } & \multirow[b]{2}{*}{$\mathrm{n}$} & \multirow[b]{2}{*}{ Mean } & \multirow[b]{2}{*}{ Median } & \multirow[b]{2}{*}{ Minimum } & \multirow[b]{2}{*}{ Maximum } & \multirow[b]{2}{*}{ ss } & \multicolumn{4}{|c|}{ Kruskal-Wallis $\mathrm{H}$ test } \\
\hline & & & & & & & & Rank Average & $\mathrm{H}$ & $\mathrm{p}$ & $\begin{array}{l}\text { Significant } \\
\text { Differences }\end{array}$ \\
\hline \multirow{5}{*}{ Motivation } & Reading & 94 & 31.72 & 32.00 & 20.00 & 36.00 & 3.57 & 193.95 & & & \\
\hline & Watching TV & 174 & 29.77 & 30.00 & 11.00 & 36.00 & 3.83 & 142.50 & & & $2-1 *$ \\
\hline & Movie- Theatre & 21 & 32.24 & 32.00 & 25.00 & 36.00 & 3.43 & 209.24 & 24.6 & 0.0001 & $2-3 *$ \\
\hline & Sports Activities & 44 & 31.50 & 31.50 & 21.00 & 36.00 & 3.50 & 186.17 & & & $2-4 *$ \\
\hline & Total & 333 & 30.71 & 31.00 & 11.00 & 36.00 & 3.81 & & & & \\
\hline \multirow{5}{*}{ Perseverance } & Reading & 94 & 28.85 & 30.00 & 16.00 & 36.00 & 4.44 & 192.26 & & & \\
\hline & Watching TV & 174 & 26.07 & 27.00 & 9.00 & 36.00 & 5.38 & 141.17 & & & $2-1 *$ \\
\hline & Movie- Theatre & 21 & 29.48 & 32.00 & 18.00 & 36.00 & 5.78 & 205.40 & 26.6 & 0.0001 & $2-3 *$ \\
\hline & Sports Activities & 44 & 29,30 & 29.00 & 19.00 & 36.00 & 4.16 & 196.85 & & & $2-4 *$ \\
\hline & Total & 333 & 27.50 & 28.00 & 9.00 & 36.00 & 5.21 & & & & \\
\hline \multirow{5}{*}{$\begin{array}{c}\text { Lack of Learning } \\
\text { Organization Skills }\end{array}$} & Reading & 94 & 17.33 & 16.00 & 6.00 & 35.00 & 8.43 & 161.04 & & & \\
\hline & Watching TV & 174 & 18.35 & 19.00 & 6.00 & 36.00 & 7.71 & 174.96 & & & \\
\hline & Movie- Theatre & 21 & 17.86 & 16.00 & 6.00 & 33.00 & 9.23 & 164.74 & 3.04 & 0.384 & - \\
\hline & Sports Activities & 44 & 16.36 & 12.50 & 6.00 & 35.00 & 8.45 & 149.34 & & & \\
\hline & Total & 333 & 17.77 & 17.00 & 6.00 & 36.00 & 8.11 & & & & \\
\hline \multirow{5}{*}{ Lack of Curiosity } & Reading & 94 & 24.18 & 20.50 & 9.00 & 49.00 & 11.44 & 131.91 & & & \\
\hline & Watching TV & 174 & 29.95 & 31.00 & 9.00 & 53.00 & 10.38 & 183.28 & & & $1-2 * *$ \\
\hline & Movie- Theatre & 21 & 29.00 & 28.00 & 9.00 & 54.00 & 12.49 & 171.98 & 17.8 & 0.0001 & $1-3^{* *}$ \\
\hline & Sports Activities & 44 & 29.16 & 28.50 & 9.00 & 49.00 & 11.51 & 175.22 & & & $1-4^{* *}$ \\
\hline & Total & 333 & 28.16 & 28.00 & 9.00 & 54.00 & 11.21 & & & & \\
\hline \multirow{5}{*}{$\begin{array}{l}\text { Lifelong Learning } \\
\text { Tendency Scale }\end{array}$} & Reading & 94 & 102.09 & 98.00 & 72.00 & 151.00 & 18.31 & 153.07 & & & \\
\hline & Watching TV & 174 & 104.14 & 102.00 & 58.00 & 157.00 & 17.83 & 169.70 & & & \\
\hline & Movie- Theatre & 21 & 108.57 & 102.00 & 79.00 & 144.00 & 21.04 & 183.29 & 3.3 & 0.346 & - \\
\hline & Sports Activities & 44 & 106.32 & 101.00 & 79.00 & 150.00 & 17.51 & 178.31 & & & \\
\hline & Total & 333 & 104.13 & 100.00 & 58.00 & 157.00 & 18.14 & & & & \\
\hline
\end{tabular}

\section{Results, Conclusions and Recommendations}

In the present study, which aims to investigate the opinions of students from midwifery and nursing departments regarding lifelong learning, it was determined that the mean scores from the Scale for Measuring the Lifelong Learning Tendencies were less than the mean scale score, which suggests that the lifelong learning tendencies of the participant students were at a low level. Accordingly, it could be considered that students are not sufficiently interested in participating in lifelong learning and other relevant activities; they experience difficulties with organizing and maintaining lifelong learning activities; and they lack curiosity, one of the fundamental determinants of lifelong learning. According to a review of the relevant literature, there are studies supporting our findings. Çoşkun (2009), in a study conducted on university students, reported low lifelong learning tendency levels. On the contrary, Kuzu, Demir and Canpolat (2015) concluded that the lifelong learning tendencies of prospective teachers were at the same level as those reported by Oral and Yazar (2015). Örs (2016a) reported high lifelong learning tendency levels in teachers. Schuch, Shouping and Gaston (2009) stated that even though students possess the skills necessary for their areas of study, their fundamental research and learning skills were inadequate and, accordingly, educational programs 
should be organized in an inter-disciplinary form which includes creative activities so that they can gain these skills. To that end, on- or off-campus systems need to be built, which would allow students to access continuous learning resources (libraries, internet, courses, seminars etc.) conveniently; also, students need to be encouraged to use these resources effectively. Students can read books to access information, do research on the internet, display curiosity and persevere with their learning.

According to our results, the students' lifelong learning tendencies show statistically significant differences in terms of the gender and leisure activity variables. The Mann-Whitney U Test results show that the mean scores of the female and male students are statistically significantly different; this difference was greater for the male students $(p<0.05)$. The male students' lifelong learning tendency levels were found to be higher than those of the female students. On the other hand, whereas Özçiftçi and Çakır (2015) concluded that female students' lifelong learning tendencies were higher than those of male students, Kılıç (2015), in a study conducted on senior students from five different branches, found that female students have a more positive attitude towards lifelong learning with respect to male students. Also in a work conducted by Adabaş and Kaygin (2016) it was pointed out that gender is an effective factor on lifelong learning competences. It can be seen that our finding is consistent with the literature. It can be seen that our finding is consistent with the literature.

Furthermore, the relationship between midwifery and nursing students' leisure activities and their lifelong learning tendencies was investigated using a Kruskal-Wallis H Test. As a result of this test, a statistically significant relationship was determined between reading and watching TV. It was observed that there was a significant difference between the students' lifelong learning tendencies with respect to reading and watching TV, but no difference was found among students with respect to sports activities and going to the movie-theatre. It was observed that the significant difference was on the advantage of students who prefer Reading and TV as leisure activities. Similar findings have been reported in the relevant literature. A similar result was found by Karaduman (2015) in his study conducted on university students. İzci and Koç (2012) reported a significant difference between the lifelong learning-related opinions of teachers from classroom, math and Turkish branches and their utilization rate from library; and this significant difference was on the advantage of the one who utilize from library. This study's findings suggest that the students' department does not cause a significant difference between their lifelong learning tendencies. In this regard, different findings have been reported in the literature: By Oral and Yazar (2015), and Kılıç (2014), in their studies conducted on prospective teachers; by Karaduman (2015), in his study conducted on university students; and by Örs (2016a), in his study conducted on teachers, all concluded that lifelong learning tendencies do not show any significant differences with respect to department. Contrary to these findings, İzci and Koç (2012), and Çoşkun (2009) concluded in their studies that there were significant differences with respect to department.

In light of the primary findings, it can be concluded that the lifelong learning paradigm needs to be more efficient in School of Health and Faculties of health sciences across Turkey; and that teaching and learning processes need to be re-organized along these lines. Appropriate motivational environments at universities supporting lifelong learning opportunities need to be established. Moreover, relevant orientation sessions need to be offered to freshman students regarding accessing information resources, and these programs should be updated and repeated in the future.

Lifelong learning relevant courses must be included in the curricula of School of Health and Faculties of Health Sciences.

One of the main obstacles to participating in adult education is the failure to communicate those educational resources to public. Lots of educational activities are arranged by universities, district public education centers as well as volunteer organizations, which students could be interested in and, in fact, need. Midwifery and nursing students must be informed about these activities as effective and adequate.

The lifelong learning tendencies of midwifery and nursing students could be investigated more comprehensively by means of qualitative and qualitative studies. Furthermore, studies comparing the lifelong learning tendencies of midwifery and nursing students from overseas and Turkey could be conducted.

\section{REFERENCES}

[1] Abruzzese, R. S. (1986). Nursing staff development strategies for success. 2nd. ed., Mosby Company, St. Louis.

[2] Adabaş, A., Kaygın, H. (2016). Lifelong Learning Key Competence Levels of Graduate Students. Universal Journal of Educational Research 4(12A): 31-38.

[3] Ahmed, M. (2002). Lifelong learning and the learning society. In M. Singh (Ed). Institutionalising lifelong learning: Creating conducive environments for adult learning in the Asian context, 22-43. UNESCO Institute for Education.

[4] Alspach, G. J. (1995). The educational process in nursing staff development. Mosby Company, St. Louis.

[5] Aspin, D., \& Chapman, J. (2000). Lifelong learning: Concept and conceptions. International Journal of Lifelong Education, 19(1):2-19.

[6] Barnard, A., Nash, R., \& O’Brien, M. (2005). Information literacy: Developing lifelong skills through nursing education. The Journal of Nursing Education, 44(11): 505-510. 
[7] Büyüköztürk, Şener., Çakmak, Ebru K., Akgün, Özcan E., Karadeniz, Şirin., Demirel, Funda. (2010). Bilimsel araştırma yöntemleri. (5. Baskı) Pegem Akademi, Ankara.

[8] Candy, P. C. (2003). Lifelong learning and information literacy. Report for the U.S. National Commission on Libraries and Information Science and the National Forum on Information Literacy.

[9] Crick, R. D., Broadfoot, P., \& Claxton, G. (2004). Developing an effective lifelong learning inventory: the ELLI project. Assessment in Education: Principles, Policy \& Practice, 11(3), 247-272.

[10] Çoşkun, Y. D. (2009). Üniversite öğrencilerinin yaşam boyu öğrenme eğilimlerinin çeşitli değişkenler açısından incelenmesi. Yayınlanmamış Doktora Tezi, Hacettepe Üniversitesi, Sosyal Bilimler Enstitüsü, Ankara.

[11] Dickinson, M. (2000). An analysis of the accreditation of transferable skills in extra-curricular activities within higher education. Assessment and Evaluation in Higher Education, 25(1): 61-70.

[12] Epçaçan, C. (2013). Yaşam boyu öğrenme becerilerinin ders kitaplarında yer alma düzeyine örnek bir inceleme. Adryaman Üniversitesi Sosyal Bilimler Enstitüsü Dergisi, 11,353-379.

[13] European Commission (2002). European report on quality indicators of lifelong learning. Fifteen Quality Indicators. European Commission Report, Directorate-General for Education and Culture, Brussels.

[14] Gallagher, L. (2007). Continuing education in nursing: A concept analysis. Nurse Education Today, 27(5): 466-473.

[15] Gopee, N. (2005). Facilitating the implementation of lifelong learning in nursing. British. Journal of Nursing, 14(4): 761-767.

[16] Gopee, N. (2002). Human and social capital as facilitators of lifelong learning in nursing. Nurse Education Today, 22: 608-616.

[17] Gökçebay, N., Bakır, S., Mutlu, G., Kaya, B. (1997). Hemşirelik sürekli eğitim ve klinik. IV. Ulusal Hemşirelik Kongresi, 10-12 Eylül, Kıbrıs, 294-296.

[18] Hinchliffe, S. (1994). Learning for life. Nursing Standard, 8(48): $20-21$.

[19] İzci, E. ve Koç, S. (2012). Öğretmen adaylarının yaşam boyu öğrenmeye ilişkin görüşlerinin değerlendirilmesi. Adıyaman Üniversitesi Sosyal Bilimler Enstitü Dergisi, 9, 101-114.

[20] Kalayc1, şeref. (2010). SPSS uygulamalı, çok değişkenli istatistik teknikleri. (5.Baskı) Asil yayın dağıtım, Ankara.

[21] Karaduman, A. (2015). Üniversite öğrencilerinin yaşam boyu öğrenme eğilimleri ile özyeterlik algıları arasındaki ilişki. Yayınlanmamış Yüksek Lisans Tezi, Bartın Üniversitesi, Eğiitm Bilimleri Enstitüsü, Bartın.

[22] Karasar, N. (2014). Bilimsel araştırma yöntemi (26.basım). Ankara: Nobel yayınları.
[23] Kuzu, S., Demir, S. ve Canpolat, M. (2015).Öğretmen adaylarının yaşam boyu öğrenme eğilimlerinin bazı değişkenler açısından değerlendirilmesi. Eğitimde Kuram ve Uygulama, 11(4), 1089-1105.

[24] Kılıç, Ç. (2014). Öğretmen adaylarının yaşam boyu öğrenmeye yönelik algıları. Ĕgitim ve Öğretim Araștırmaları Dergisi/Journal of Research in Education and Teaching, 3(4), 79-87.

[25] LLCQ.(2017). Lifelong learning Council Queensland Inc. Supporting and promoting adult and community learning. Available at:

http://www.llcq.org.au/01 cms/details.asp?ID=4. Accessed June5, 201

[26] Maslin, S. E. (1997). A perspective on lifelong learning and its implications for nurses. Nurse Education Today, 17: $431-436$

[27] Mouzakitıs, G., Tuncay, N. E. (2011). E-learning and lifelong learning. Turkish Online Journal of Distance Education-TOJDE, 12(1), http://tojde.anadolu.edu.tr/tojde41/articles/article_9.htm

[28] Miser, R. (2013).Yaşam boyu öğrenme kavram ve bağlam (1.Basım). Ankara: EBF-MD Yayınları.

[29] Oral, B. ve Yazar, T. (2015). Öğretmen adaylarının yaşam boyu öğrenmeye ilişkin algılarının çeşitli değişkenlere göre incelenmesi. Elektronik Sosyal Bilimler Dergisi, 14(52), $1-11$.

[30] Örs, M. (2016a). İlkokul öğretmenlerinin yașam boyu ögrenme eğilimlerinin incelenmesi. Babaoğlan, E., Kıral, E., Cilek, A. (Ed). Eğitime Dönüs içinde (ss. 87-101). Ankara: EYUDER YAYINLARI (1.Bask1) www.eyuder.org

[31] Örs, M. (2016b). Condition of primary schools in Terms of social health. Lambert Academic Publishing, Germany.

[32] Özçiftçi, M. ve Çakır, R. (2015). Öğretmenlerin yaşam boyu öğrenme eğilimleri ve eğitim teknolojisi standartları özyeterliklerinin incelenmesi. Eğitim Teknolojisi Kuram ve Uygulama. 5(1), 1-19.

[33] Schuch, K., Shouping, H., \& Gaston, G.J. (2009). Motivation in education: Theory, research, and applications. $\mathrm{NJ}$ Merrill Prentice Hall.

[34] Stein, A. (1998). History of continuing nursing education in The United States. The Journal of Continuing Education in Nursing, 29(6): 245-252.

[35] Taşocak, G. (2000). Eğitimde süreklilik. I. Ulusal klinisyen hemsireler ve ebeler kongresi, 4-7 Mayıs, Antalya

[36] Titmus, C. (1999). Concepts and practices of education and adult education: Obstacles to lifelong education and lifelong learning. International Journal of Lifelong Education, 18(3): 343-354.

[37] Thurstone, H. (1992). Mandatory continuing education: What the research tell us. The Journal of Continuing Education in Nursing, 23(1): 6-14. 